\title{
RANCANG BANGUN MODEL KELEMBAGAAN AGRIBISNIS PADI ORGANIK DALAM MENDUKUNG KETAHANAN PANGAN
}

\author{
Kusnandar, Dwiningtyas Padmaningrum, Wiwit Rahayu, dan Agung Wibowo \\ Fakultas Pertanian Universitas Sebelas Maret \\ Jalan Ir. Sutami 36A Surakarta 57126 Indonesia Telepon: 62-271-637457 \\ E-mail: kusnan_dar@yahoo.com
}

Diterima 29 Agustus 2012 / Disetujui 4 April 2013

\begin{abstract}
The aim of this research was to design an institutional model for organic rice agribusiness. Data were collected through interviews and focus group discussion which includes the primary and secondary data. Data analysis methods for organic rice agribusiness institutional development were: system analysis, institutional analysis and interactive analysis. Result of the research indicated that organic rice agribusiness system in Sragen was supported by a strong superstructures. There were Go Organic 2010 program and many policies of Sragen government includes: cultivation, extension, marketing, and certification. Profile community of organic rice agribusiness includes organic rice farmers, farmer groups, associations of farmer groups (gapoktan), extension agents, organic rice farmer associations, organic rice agro-industry companies, government, and consumers. Designing models with the agribusiness system suggested a cluster of industry (industrial cluster) which composed of five subsystems, namely: upstream agribusiness, on farm agribusiness, down stream agribusiness, supporting agribusiness system, and marketing subsystem.
\end{abstract}

Key words: institutional, agribusiness, food security, model, organic rice

\begin{abstract}
Abstrak: Penelitian ini bertujuan untuk merancang bangun model kelembagaan agribisnis padi organik. Data yang dikumpulkan meliputi data primer dan data sekunder. Analisis data meliputi analisis sistem, analisis kelembagaan, dan interaktif analisis. Hasil analisis menunjukkan bahwa sistem agribisnis padi organik di Kabupaten Sragen didukung oleh superstruktur yang kuat yaitu kebijakan pemerintah pusat berupa program Go organik 2010 dan kebijakan pemerintah daerah berupa budidaya, penyuluhan, pemasaran, dan sertifikasi. Profil komunitas agribisnis padi organik meliputi petani, kelompok tani, gapoktan, penyuluh, asosiasi petani padi organik (APO), perusahaan agroindustri beras organik, pemerintah, dan konsumen. Rancang bangun model didesain dengan mengacu pada sistem agribisnis. Suatu sistem agribisnis yang lengkap merupakan suatu gugusan industri (industrial cluster) yang terdiri dari lima subsistem yaitu: subsistem agribisnis hulu (upstream agribusiness), subsistem usahatani (on farm agribusiness), Subsistem hilir (downstream agribusiness), subsistem penunjang (supporting system agribusiness), dan subsistem pemasaran.
\end{abstract}

Kata kunci: kelembagaan, agribisnis, ketahanan pangan, model, padi organik

\section{PENDAHULUAN}

Ketahanan pangan didefinisikan sebagai kondisi terpenuhinya pangan bagi rumah tangga yang tercermin dari tersedianya pangan yang cukup. Sisi ketersediaan menurut Nainggolan (2005) berarti tersedianya pangan yang cukup bagi seluruh penduduk dalam jumlah, mutu, keamanan, dan keterjangkauan. Konsep ketahanan pangan mengalami evolusi dalam beberapa dekade. Pada tahun 1970an konsep ketahanan pangan menekankan pada ketersediaan pangan, sedangkan sejak tahun 1980an konsep ketahanan pangan bergeser pada fokus akses pangan baik fisik maupun ekonomi (Catula et al, 2008). 
Ketersediaan pangan sampai pada tingkat rumah tangga merupakan kriteria ketahanan pangan. Kondisi wilayah Indonesia yang sangat luas yang penduduknya tersebar di seluruh pulau-pulau inilah yang menyebabkan salah satu hambatan untuk menciptakan ketahanan pangan. Kasus kerawanan pangan masih sering terjadi meskipun persediaan pangan secara nasional cukup. Pada sisi lain Purwaningsih et al (2010) menyatakan bahwa distribusi rumah tangga menurut tingkat ketahanan pangan di Jawa Tengah menunjukkan bahwa proporsi rumah tangga rentan pangan merupakan yang terbesar.

Ketersediaan pangan tidak cukup menjamin adanya ketahanan pangan karena belum tentu masyarakat dapat mengakses pangan dengan baik. Pada perkembangannya akses pangan ini harus memenuhi kuantitas dan kualitas dari pangan yang diakses sehingga mutu dan keamanan pangan menjadi hal yang penting dalam menjaga ketahanan pangan. Trend keamanan pangan (food safety) menjadi isu sensitif dalam industri pangan, dan berimbas pada perkembangan pangan organik, yang bersumber pada potensi lokal, sekaligus aman untuk dikonsumsi.

Penurunan produktifitas padi yang salah satunya disebabkan oleh intensifikasi dengan teknologi Revolusi Hijau, telah menjadi ancaman bagi pemenuhan kebutuhan beras dalam pemantapan ketahanan pangan. Hal ini menjadi salah satu pendorong kegiatan pertanian organik. Colborn (2006).mengatakan bahwa pangan organik adalah pangan yang berkaitan dengan cara-cara produksi organik hanya apabila pangan tersebut berasal dari suatu lahan pertanian organik yang menerapkan praktek-praktek pengelolaan yang bertujuan untuk memelihara ekosistem untuk mencapai produktivitas yang berkelanjutan, dan melakukan pengendalian gulma, hama dan penyakit, melalui berbagai cara seperti daur ulang residu tumbuhan dan ternak, seleksi dan pergiliran tanaman, pengelolaan pengairan, pengolahan lahan dan penanaman serta penggunaan bahanbahan hayati.

Beras organik merupakan salah satu produk pangan yang memiliki peluang untuk dikembangkan dalam suatu sistem agribsinis.
Secara empirik sistem agribisnis yang berdaya saing dicirikan oleh dua kondisi yaitu: adanya kaitan fungsional antara bidang agribisnis dan lembaga pendukung agribisnis, dan adanya kaitan institusional di antara bidang agribisnis. Kaitan yang serasi di antara bidang agribisnis menyebabkan sistem agribisnis bersifat efektif dalam merespon dinamika pasar output. Sedangkan kaitan institusional menyebabkan sistem agribisnis bersifat efisien. Hal ini karena adanya kaitan institusional tersebut menyebabkan seluruh kegiatan agribisnis berada dalam satu kendali kegiatan, dan "marjin ganda" serta "sharing system" yang tidak adil di antara pelaku agribisnis dapat ditekan (Litbang Deptan, 2007). Oleh karena itu pengembangan kelembagaan harus mempertimbangkan aspek ekonomi, kelembagaan ekonomi berasumsi bahwa pilihan rasional individu harus mengarah pada efisiensi sebagai pengaturan kelembagaan yang mempunyai biaya transaksi paling sedikit (Lieberherr, 2009).

Pengembangan agribisnis ramah lingkungan merupakan agribisnis yang dari segi perencanaan usaha telah memperhitungkan dukungan kekuatan alam secara berkelanjutan. Tingkat eksploitasi terhadap sumberdaya alam disesuaikan dengan daya dukung dan resistensi sumberdaya alam yang ada, sehingga produktivitas sumberdaya setempat dari waktu ke waktu tetaplah stabil. Alternatif lain pengurasan atau pengrusakan akibat kegiatan agribisnis diupayakan ditanggulangi dengan penambahan investasi yang dikhususkan untuk mengembalikan mutu sumberdaya alam seperti semula atau (paling tidak) seperti sebelum diusahakan (Pranadji, 2003). Keberlanjutan sebuah inovasi melampaui tahap ide tergantung pada bagaimana para pelaku mengubah norma-norma dan pola interaksi melalui inovasi kelembagaan (Prasad, 2007).

Konsekuensi logis dalam melaksanakan pembangunan pertanian adalah mendorong inovasi kelembagaan dengan keahlian yang meliputi pengetahuan pasar, agribisnis dan keuangan pedesaan (Adekunle et al, 2012). Oleh sebab itu penganalisisan kelembagaan tersebut sangat diperlukan agar kondisi yang sebenarnya dapat diketahui secara mendalam dan dapat menentukan langkah perbaikan jika 
masih terdapat kelemahan dalam kelembagaan tersebut guna kemajuan agribisnis yang dijalankan. Untuk melakukan perubahan kelembagaan maka harus melakukan pemetaan dan analisis keterkaitannya, sehingga perlu mengidentifikasi pelaku, mekanisme kelembagaan dan peluang dan tantangan yang dihadapi petani kecil (Hounkonnou, 2012)

Analisis kelembagaan dalam bidang pertanian adalah analisis yang ditujukan untuk memperoleh deskripsi mengenai suatu fenomena sosial ekonomi pertanian, yang berkaitan dengan hubungan antara dua atau lebih pelaku interaksi sosial ekonomi, mencakup dinamika aturan-aturan yang berlaku dan disepakati bersama oleh para pelaku interaksi, disertai dengan analisis mengenai hasil akhir yang diperoleh dari interaksi yang terjadi. Dalam batas-batas tertentu analisis kelembagaan dapat berlaku umum di berbagai wilayah dan keadaan, namun dalam banyak hal, aspek lokalitas dan permasalahan spesifik harus selalu memperoleh penekanan, mengingat peluang besar terjadinya variasi per lokalitas maupun permasalahan (Syahyuti, 2002).

Aspek kelembagaan merupakan syarat pokok agar struktur pertanian pedesaan maju. Saleh et al (2007) mengatakan bahwa kelembagaan merupakan faktor penting dalam mengatur hubungan antarindividu untuk penguasaan faktor produksi yang langka. Kelembagaan memiliki peran strategis, namun menurut Soekartawi (2001) aspek kelembagaan baik kelembagaan formal maupun kelembagaan non formal justru merupakan aspek menonjol yang dapat menghambat jalannya pembangunan pertanian di negara-negara yang sedang berkembang. Hal ini terjadi karena masih banyaknya kelembagaan yang belum optimal yang ada di negara-negara berkembang termasuk di Indonesia.

Kelembagaan merupakan hal yang komplek karena banyak faktor yang mempengaruhi keberlangsungan kelembagaan itu. Kelembagaan tidak bisa hanya dilihat dari segi internal kelembagaan tetapi juga dari segi eksternal kelembagaan yang mempengaruhi kegiatan kelembagaan tersebut. Oleh sebab itu, penganalisisan kelembagaan tersebut sangat diperlukan agar kondisi yang sebenarnya dapat diketahui secara mendalam dan dapat menentukan langkah perbaikan jika masih terdapat kelemahan dalam kelembagaan tersebut guna kemajuan agribisnis yang dijalankan. Sejalan dengan pemikiran mengenai analisis kelembagaan, penelitian ini bertujuan untuk merancang bangun model kelembagaan agribisnis padi organik yang bisa diterapkan dalam pengembangan agribisnis padi organik.

\section{METODE PENELITIAN}

Penelitian dilakukan di kabupaten Sragen yang mempunyai komitmen terhadap pengembangan padi organik. Kabupaten Sragen mempunyai luas wilayah padi organik cukup besar yang tersebar di 20 kecamatan dan pada tahun 2010 mencapai areal luas panen 9.244 Hektar.

Data dan informasi yang digunakan dalam penelitian ini meliputi data primer dan data sekunder. Metode pengumpulan data dilakukan melalui observasi, survey, indepth interview serta focus group discussion, dengan responden terdiri dari: petani padi organik, gapoktan, asosiasi padi organik, penyuluh lapangan, BAPELLUH, pengusaha beras organik (PT Padi Mulya), lembaga keuangan (Bank Jateng). Pengumpulan data dan informasi untuk analisis sistem dilakukan wawancara mendalam dengan responden yang terkait. Data yang berkaitan dengan super struktur profil komunitas (community profile) dan profil kelembagaan (organizational profile) dieroleh melalui wawancara mendalam dan observasi lapang sedangkan pengumpulan data dan informasi model kelembagaan dan pola hubungan kelembagaan dilakukan melalui Focus Group Discusion (FGD).

Analisis data dilakukan dengan menggunakan analisis sistem melalui analisis kebutuhan, formulasi masalah serta identifikasi sistem agribisnis padi organik. Kondisi kelembagaan dianalisis dengan analisis interaktif yang meliputi: reduksi data, sajian data, penarikan simpulan (Sutopo, 2006). Rancang bangun model kelembagaan agribisnis padi organik yang bisa diterapkan dalam pengembangan agribisnis padi organik di kabupaten Sragen dilakukan dengan metode Focus Group Discussion (FGD), yang melibatkan semua stakeholder dalam agri- 


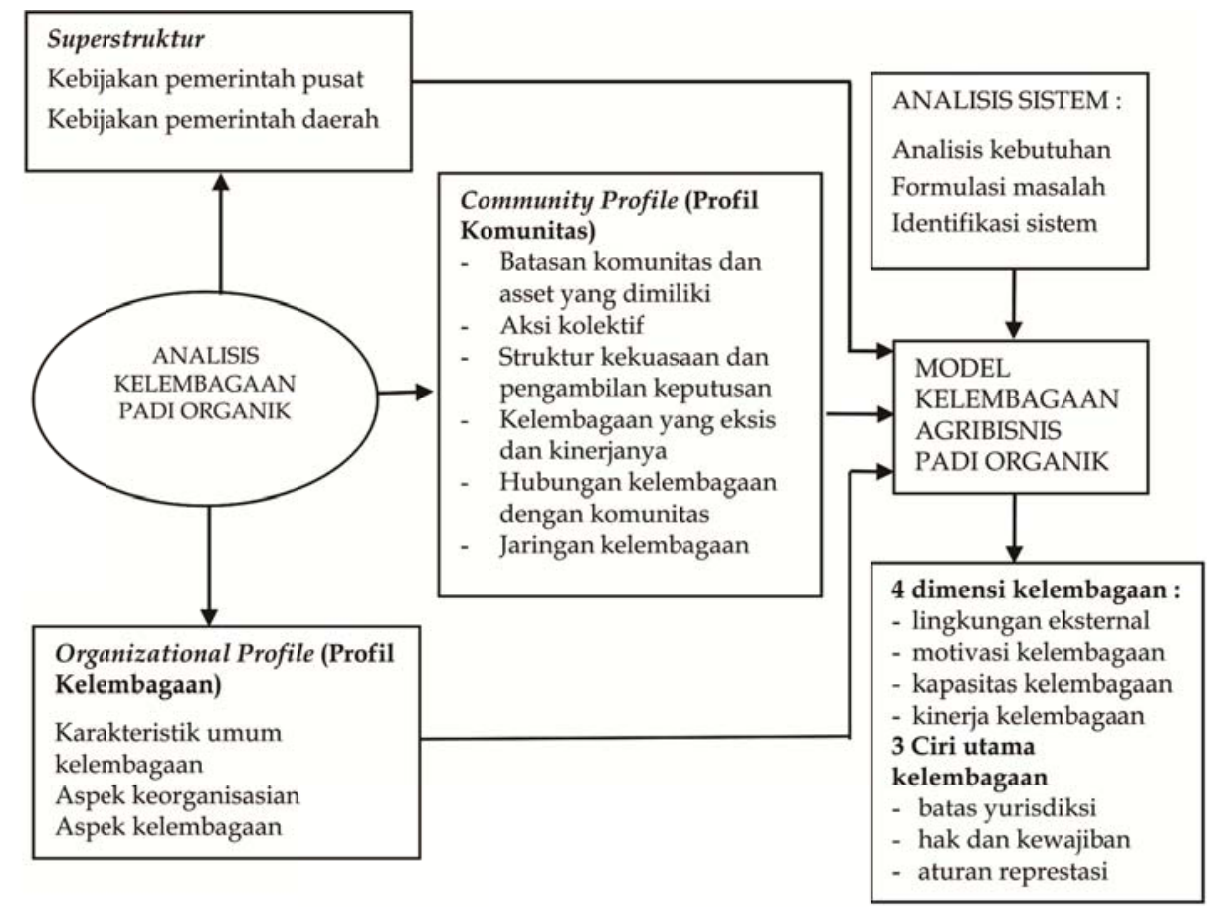

Gambar 1. Kerangka Pikir Penelitian

bisnis padi organik. Secara skematis kerangka pikir penelitian dapat dilihat pada Gambar 1.

\section{HASIL DAN PEMBAHASAN}

\section{Analisis Sistem Agribisnis Padi Organik}

Sistem agribisnis padi organik terdiri dari beberapa pelaku yang terlibat dalam sistem tersebut. Adapun pelaku yang terlibat dalam sistem agribisnis padi organik meliputi: petani padi organik, agroindustri beras organik, kelompok tani, gapoktan, peternak sapi, asosiasi padi organik, BAPELLUH, lembaga keuangan dan konsumen. Hasil analisis terhadap permasalahan sistem agribisnis padi organik menunjukkan bahwa permasalahan yang sering muncul dalam sistem agribisnis padi organik adalah ketergantungan terhadap pupuk dan pestisida kimia yang masih cukup tinggi sehingga proses penggatian pupuk organik secara total perlu pemahaman secara bersama dalam kelompok. Ketersediaan modal dalam mengatasi pembayaran tunda yang dilakukan agroindustri beras organik dan asosiasi masih merupakan permasalahan yang penting untuk dicarikan solusinya.

\section{Analisis Kelembagaan Agribisnis Padi Organik}

Analisis kelembagaan agribisnis padi organik menunjukkan superstruktur yang mendukung kelembagaan sangat kuat yakni berupa dukungan kebijakan pemerintah pusat berupa program Go organik 2010 dan kebijakan pemerintah daerah yang menyangkut kebijakan mulai dari budidaya, penyuluhan, pemasaran, dan sertifikasi. Dukungan pemerintah daerah sangat penting dalam pengembangan agribisnis padi organik. Hal ini sejalan dengan penelitian Kusnandar dan Marimin (2003) yang menyatakan bahwa pengembangan agroindustri jamu pemerintah daearah merupakan elemen kunci dalam struktur elemen pelaku pengembangan. Profil komunitas kelembagaan agribisnis padi organik mempunyai interseksi yang cukup kuat antar antara kelompok petani, kelompok peternak, perkumpulan petani pemakai air (P3A) dan asosiasi padi organik hal ini akan sangat mendukung dalam mendesain kelembagaan. Profil kelembagaan pada masing-masing pela$\mathrm{ku}$ sistem agribisnis padi organik sudah terbentuk dengan baik sehingga problem utamanya adalah bagaimana menyatukan masing-masing 
profil tersebut dalam satu kesatuan sistem kelembagaan.

\section{Kelembagaan Agribisnis Hulu (Upstream Agribusiness) Padi Organik}

Salah satu subsistem dalam sistem agribisnis padi organik adalah subsistem agribisnis hulu. Peran subsistem agribisnis hulu adalah menghasilkan barang-barang modal bagi proses produksi pertanian yaitu usaha-usaha dalam bidang perbenihan/pembibitan tumbuhan dan hewan, industri agrokimia (pupuk, pestisida, obat/vaksin ternak) dan industri agro-otomotif (mesin dan peralatan pertanian) serta industri pendukungnya. Kelembagaan pada subsistem agribisnis hulu bertujuan untuk menjamin terpenuhinya input yang dibutuhkan pada subsistem usahatani. Input paling krusial dalam subsistem usahtani padi organik adalah pupuk dan pestisida organik. Kelembagaan pada subsistem ini harus mampu menjamin terpenuhinya kebutuhan tersebut sehingga rancang bangun kelembagaan pada subsistem agribisnis hulu mencakup kelembagaan peternak dan kelembagaan produsen ternak. Terjaminnya kelembagaan ini maka keberlanjutan agribisnis padi organik yang menyediaan pangan bermutu untuk mendukung ketahanan pangan dapat berjalan berkesinambungan.

Faktor yang sangat krusial pada agribisnis padi organik adalah ketersedian pupuk dan pestisida organik yang merupakan input utama dalam agribisnis padi organik. Pupuk dan pestisida organik harus dijamin kemurniannya terhadap kantaminan bahan yang bukan organik. Kelembagaan penyediaan pupuk dan pestisida organik meliputi dua unsur yaitu peternak sebagai penyediaa bahan baku pupuk dan pestidida organik dan produsen pupuk dan pestisida organik yang mengolah kotoran ternak menjadi pupuk dan pestisida. Kelompok peternak dan kelompok produsen pupuk organik menjadi alternatif yang paling memungkinkan dalam desain kelembagaan ini. Keanggotaan kelompok peternak dan kelompok produsen ternak hampir sama meskipun tidak sama persis karena seorang peternak tidak otomatis sebagai produsen pupuk dan produsen pupuk belum tentu sebagai peternak meskipun bisa menjadi anggota keduanya.

\section{Kelembagaan Usahatani (On Farm Agribusiness) Padi Organik}

Subsistem yang kedua pada kelembagaan padi organik adalah subsistem usahatani. Peran subsistem usahatani adalah melakukan kegiatan yang menggunakan barang-barang modal dan sumberdaya alam untuk menghasilkan komoditas pertanian primer. Kelembagaan pada subsistem usahatani bertujuan untuk menghasilkan produk primer pertanian yang merupakan bahan baku bagi subsistem agribisnis hilir. Pada kelembagaan ini produk primer yang dihasilkan adalah padi organik yang akan diproses lebih lanjut menjadi beras organik pada subsistem agribisnis hulu.

Pelaku utama pada subsistem ini adalah kelompok tani yang tergabung dalam Gabungan Kelompok Tani (Gapoktan). Kelembagaan kelompok tani pada agribisnis padi organik ini sudah menggunakan manajemen modern yang dibakukan dalam menjalankan segala aktifitas mulai dari pengelolaan tanah, pembibitan, penanaman, pemeliharaan, panen sampai pasca panen. Manajemen mutu sudah diterapkan dalam kelompok tani dengan fasilitasi oleh penyuluh pertanian lapangan serta melibatkan asosiasi padi organik (APO) untuk menjamin produk primer padi organik yang memenuhi persyaratan beras organik.

Penjaminan mutu pada proses budidaya padi organik merupakan persyaratan mutlak yang harus dilakukan oleh subsistem ini karena produk yang dihasilkan dapat diterima oleh subsistem hulu tidak hanya sekedar output berupa padi hasil budidaya tetapi proses produksi untuk menghasilkan output tersebut sangat penting. Keterkaitan kelompok tani, asosiasi padi organik, perusahaan beras organik sangat erat dalam proses budidaya. Keterlibatan asosisasi padi organik dan perusahaan beras organik dilakukan dalam menjamin proses budidaya dilakukan secara benar, Perusahaan beras organik secara berkala melakukan supervisi untuk memastikan bahwa proses budidaya memenuhi persyaratan bagi bahan baku yang dibutuhkan untuk menghasilkan beras organik. Asosiasi berperan dalam pendampingan dan supervisi pada proses budidaya sehingga budidaya padi organik tidak menyimpang dari prosedur yang telah ditetapkan. Terjaminnya 
kelembagaan ini maka keberlanjutan kelembagaan agribisnis padi organik juga akan terjamin sehingga kontribusi dalam menyediaan pangan bermutu untuk mendukung ketahanan pangan dapat berjalan berkesinambungan.

\section{Kelembagaan Agribisnis Hilir (Downstream Agribusiness) Padi Organik}

Subsistem yang ketiga pada kelembagaan padi organik adalah subsistem agribisnis hilir. Peran subsistem agribisnis hilir adalah melakukan melakukan proses pengolahan komoditas pertanian primer yang dihasilkan pada subsistem usahatani. Kelembagaan pada subsistem agribisnis hilir bertujuan untuk menghasilkan produk agroindustri yang mempunyai nilai tambah dibanding dengan komoditas primernya. Pada kelembagaan ini produk agroindustri yang dihasilkan adalah beras organik yang mempunyai kualitas khusus yang dijamin keamanannya dari cemaran pupuk dan pestisida non organik.

Pelaku utama pada subsistem agribisnis hilir adalah asosiasi padi organik (APO), perusahaan beras organik swasta dan perusahaan beras organik milik pemda. Kelembagaan pada subsistem agribisnis hilir padi organik menggunakan manajemen modern yang dibakukan dalam menjalankan segala aktifitas melalui penjaminan mutu produknya. Manajemen mutu diterapkan dengan baik untuk menjamin produk beras organik yang berkualitas. Sertifikasi produk oleh pihak luar sangat diperlukan dalam menjamin kualitas produk agar dapat dipercaya oleh konsumen. Melalui sertifikasi maka kontrol supervisi menjadi bagian dalam kelembagaan subsistem agribisnis hilir. Terjaminnya kelembagaan agribisnis hilir maka keberlanjutan kelembagaan agribisnis padi organik juga akan terjamin sehingga kontribusi dalam menyediaan pangan bermutu untuk mendukung ketahanan pangan dapat berjalan berkesinambungan.

\section{Kelembagaan Pemasaran Agribisnis Padi Organik}

Subsistem yang keempat pada kelembagaan padi organik adalah subsistem pemasaran. Peran subsistem pemasaran adalah melakukan melakukan pemasaran produk beras organik sampai ke konsumen. Kelembagaan pada subsistem pemasaran bertujuan untuk memastikan produk dapat diterima konsumen dengan harga yang kompetitif. Pelaku utama pada subsistem pemasaran adalah sama dengan subsistem agribisnis hilir.

\section{Kelembagaan Penunjang Agribisnis Padi Organik}

Subsistem yang kelima pada kelembagaan padi organik adalah subsistem penunjang. Peran subsistem penunjang adalah memberikan dukungan terhadap kelembagaan pada subsistem yang lain. Kelembagaan pada subsistem penunjang yang penting adalah lembaga keuangan, Bapelluh dan Perkumpulan Petani Pemakai Air (P3A). Lembaga keuangan mempunyai peran dalam mendukung permodalan yang dibutuhkan dalam pengembangan padi organik. Hubungan antara pelaku agribisnis padi organik difasilitasi oleh BAPELLUH dalam berinteraksi dengan lembaga keuangan terutama pada kelembagaan kelompok tani.

Kelembagaan pengelolaan air sangat penting dalam kerangka menjamin pasokan air yang terbebas dari pencemaran. Agribisnis padi organik yag ingin menghasilkan produk beras organik murni maka sumber air ini manjadi salah satu faktor yang menghambat pengembangan padi organik. Salah satu persyaratan untuk dapat disertifikasi menjadi produk organik maka sumber air dari pegunungan menjadi penting. Kelembagaan ini perlu dirancang karena konflik kepentingan dalam penggunaan sumber air ini cukup besar dengan kepentingan yang lain. Perkumpulan petani pemakai air (P3A) merupakan kelembagaan yang bertanggung jawab terhadap fungsi penyediaan air. Keangotaan dari P3A ini merupakan interseksi dari keanggotaan kelembagaan kelompok tani pada subsistem usahatani sehingga korelasi antarkeduanya sangat kuat untuk menjaga keberlangsungan kelembagaan pada subsistem ini. Terjaminnya kelembagaan penunjang maka keberlanjutan kelembagaan agribisnis padi organik juga akan terjamin sehingga kontribusi dalam menyediaan pangan bermutu untuk mendukung ketahanan pangan dapat berjalan berkesinambungan. 


\section{Model Kelembagaan Agribisnis Padi Organik}

Rancang bangun model kelembagaan padi organik dalam mendukung ketahanan pangan didesain dengan mengacu pada sistem agribisnis. Suatu sistem agribisnis yang lengkap merupakan suatu gugusan industri (industrial cluster) yang terdiri dari lima subsistem yaitu: (1) subsistem agribisnis hulu (upstream agribusiness) yakni seluruh industri yang menghasilkan dan memperdagangkan sarana produksi pertanian primer, seperti industri pembibitan/pembenihan, industri agrokimia, industri agro-otomotif, dan lain-lain; (2) Subsistem usahatani (on farm agribusiness), yakni kegiatan yang menggunakan sarana produksi untuk menghasilkan komoditas pertanian primer (farm product); (3) Subsistem hilir (downstream agribusiness) yakni industri yang mengolah industri primer menjadi produk olahan beserta kegiatan perdagangannya; dan (4) Subsistem penunjang (supporting system agribusiness) yakni kegiatan yang menyediakan jasa bagi ketiga subsistem diatas, seperti infrastruktur, transportasi, perkreditan, penyuluhan, pelatihan, penelitian dan pengembangan; serta (5) Subsistem pemasaran yang akan memasarkan produk yang dihasilkan dari keempat subsistem tersebut. Secara skematis model kelembagaan agribisnis padi organik dapat dilihat pada Gambar 2.

Kelembagaan agribisnis padi organik dapat ditinjau dari empat dimensi sebagaimana dikemukakan Mackay et al dalam Syahyuti (2004) yaitu kondisi lingkungan eksternal (the external environment), motivasi kelembagaan (institutional mativation), kapasitas kelembagaan (institutional capacity) dan kinerja kelembagaan (institutional performance). Kelembagaan yang desainnya diarahkan dapat memenuhi keempat dimensi tersebut sehingga efektifitas dan keberlanjutan kelembagaan dapat terjamin.

Ditinjau dari kondisi eksternal yang meliputi: politik pemerintahan, sosiokultural, teknologi, kondisi perekonomian, kelompok yang berkepentingan dan kebijakan pengelolan sumberdaya alam maka faktor tersebut cukup mendukung dalam implementasi kelembagaan tersebut. Faktor sosiokultural misalnya kelompok peternak, kelompok produsen pupuk dan pestisida, Perkumpulan Petani Pemakai Air (P3A), Gapoktan, BAPELLUH, Asosiasi Padi Organik (APO) dan agroindustri beras bukan

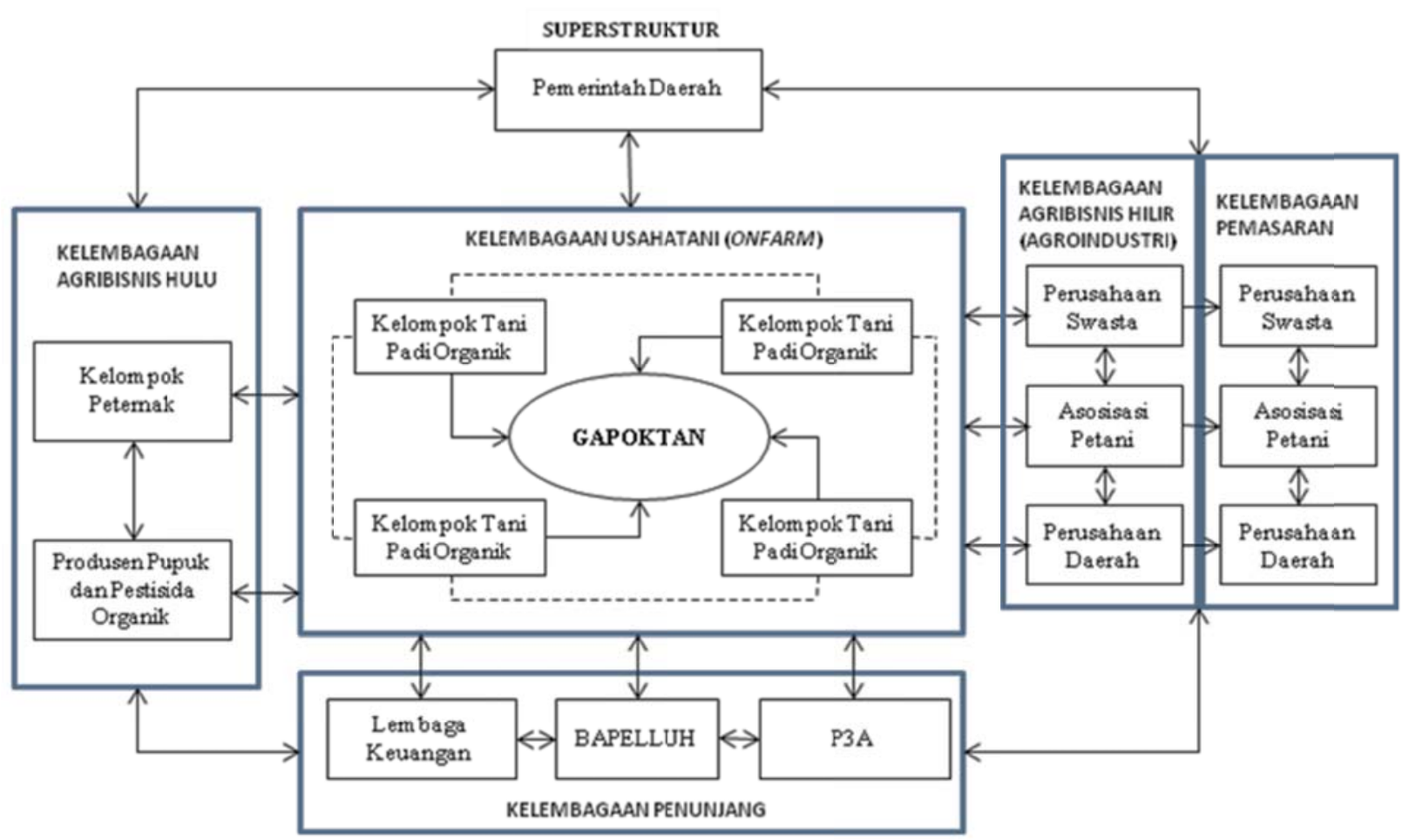

Gambar 2. Model Kelembagaan Agribisnis Padi Organik 
merupakan kelembagaan yang baru sehingga secara sosiokultural tidak ada hambatan sama sekali. Pada desain kelembagaan ini yang relatif baru adalah adanya hubungan dengan industri pupuk dan pestisida yang harus dibangun untuk meningkatkan kapasitas teknologi yang akan dikuasi oleh kelompok produsen pupuk dan pestisida sehingga lingkungan teknologi akan dapat terjamin dalam kelembagan ini. Teknologi yang mendukung kelembagaan pada subsistem usahatani difasilitasi oleh BAPELLUH, sedangkan teknologi pada subsistem hilir untuk pengolahan beras sangat tersedia dan sangat mendukung kenirja kelembagaan ini.

Apabila dilihat dari kelompok yang berkepentingan dalam kelembagaan ini maka terdapat titik temu kepentingan yang sama antara kelompok P3A, kelempok peternak, kelompok produsen pupuk dan pestisida maupun kelompok tani pada subsistem usahatani dan APO pada subsistem agribisnis hilir. Keanggotaan pada kelompok tersebut juga terdapat interseksi yang cukup kuat sehingga sinergi dan ketergantungan antara satu dengan yang lain sangat kuat.

Dimensi lain adalah motivasi kelembagaan yang meliputi: sejarah, misi yang diemban, kultur dan pola penghargaan. Sejarah pembentukan kelompok tani sudah mempunyai riwayat yang panjang dalam mengelola usahatani maupun kegiatan-kegiatan yang lain. Kelompok peternak, kelompok produsen pupuk organik merupakan perluasan dari kegiatan kelompok tani sehingga pola hubungan dan pengelolaan kelembagaan ini menjadi satu kesatuan yang tidak terpisah. Berdasarkan sejarah yang panjang dari kelompok tani ini maka desain kelembagaan yang menitik beratkan pada kelompok tani sebagai pelaku utama dalam kelembagaan agribisnis padi organik akan lebih menjamin keberlanjutan dari kelembagaan tersebut dalam menunjang ketahanan pangan pada suatu wilayah. Pembentukan asosiasi padi organik, pendirian perusahaan beras organik menjadi faktor penting dalam motivasi kelembagaan agribisnis hilir. Asosisasi padi organik sebagai salah satu pelaku dalam subsistem mempunyai peranan sentral dalam menghubungkan antara petani dengan pengusaha beras organik.

Misi yang diemban pada kelembagaan agribisnis padi organik adalah memenuhi kebutuhan masing-masing subsistem dan memberikan kontribusi pendapatan pelaku dalam sistem kelembagaan ini. Sinkronisasi antar subsistem dalam kelembagaan agribisnis padi organik merupakan kunci sukses bagi kelembagaan yang dipergunakan. Kultur kelembagaan dan pola penghargaan pada kelompok peternak dan produsen pupuk organik, kelompok tani, P3A, APO tidak berbeda karena semua pelaku dalam kelembagaan tersebut tergabung pada profil komunitas yang sama.

Dimensi kapasitas kelembagaan ditinjau dari lima aspek yaitu strategi kepemimpinan, perencanaan program, manajemen pelaksanaan, alokasi sumberdaya dan hubungan dengan pihak luar. Strategi kepemimpinan pada kelembagaan subsistem agribisnis hulu dan subsistem usahatani dikendalikan oleh ketua kelompok sebagai pengendali kepemimpinan dalam kelembagaan. Peran ketua kelompok menjadi sangat penting.

Perencanaan program dan manajemen pelaksanaannya dilaksanaakan oleh kelompok dengan difasilitasi oleh penyuluh yang tergabung dalam BAPELLUH yang menaungi PPL dalam menjalankan fungsi fasilitasi tersebut. Pendampingan oleh PPL sangat diperlukan dalam melakukan manajemen pelaksanaan. Kusnandar et al (2009) menyatakan bahwa pendampingan terhadap petani dilakukan untuk meningkatkan bargaining position petani, baik dalam kualitas kerja maupun kemampuan manajemen organisasi dan usahanya. Peran kelembagaan penyuluhan sangat penting hal ini sejalan dengan penelitian Sucihatiningsih dan Waridin (2010) yang menyatakan bahwa belum terbentuknya kelembagaan penyuluhan yang integral menyebabkan pembinaan SDM pertanian berjalan kurang optimal.

Kemampuan mengalokasikan sumberdaya yang dimiliki menjadi bagian kapasitas kelembagaan ini. Sinergi antarpetani dalam pengelolaan sumberdaya peternak dan produsen ternak pada satu sisi dan antara petani dengan APO menjadi faktor penting dalam kelembagaan ini. Hubungan dengan pihak luar pada kelembagaan ini diperankan oleh asosiasi 
produsen pupuk organik untuk menjalin hubungan dengan industri pupuk organik dan APO untuk menjalin dengan konsumen beras organik. Dimensi yang keempat adalah kinerja dari kelembagaan agribisnis padi organik yang akan tercermin dari kemampuan kelembagaan menjamin pendapatan yang dihasilkan oleh pelaku dalam sistem kelembagaan.

Tinjauan kelembagaan agribisnis padi organik juga ditinjau dari tiga ciri utama yaitu: batas yurisdiksi, hak dan kewajiban, aturan representasi. Berdasarkan batas yurisdiksi yang dimiliki oleh kelembagaan ini sangat jelas Dengan batas yurisdiksi yang jelas ini memungkinkan kelembagaan untuk mengalokasikan sumberdaya dengan baik. Hak dan kewajiban kelembagaan ini ditentukan secara jelas dalam aturan yang ada dalam kelompok dan relatif baku dan mudah difahami oleh anggota keleompok tersebut. Aturan representasi akan mengatur permasalahan siapa yang berhak berpartisipasi terhadap apa dalam proses pengambilan keputusan. Keputusan apa yang diambil dan apa akibatnya terhadap performa kelembagaan akan ditentukan oleh kaidah representasi yang digunakan. Aturan representasi dalam kelembagaan ini ditentukan dalam aturan yang sudah ditetapkan dalam aturan kelompok, sehingga apa dan siapa yang berhak dalam partisipasi pengambilan keputusan sangat jelas dalam kelembagaan tersebut.

\section{SIMPULAN}

Rancang bangun model kelembagaan padi organik dalam mendukung ketahanan pangan didesain dengan mengacu pada sistem agribisnis yang meliputi (1) subsistem agribisnis hulu (upstream agribusiness), (2) subsistem usahatani (on farm agribusiness), (3) subsistem hilir (downstream agribusiness), (4) Subsistem penunjang (supporting system agribusiness) dan (5) subsistem pemasaran. Model kelembagaan agribisnis padi organik dirancang untuk memenuhi empat dimensi yaitu: kondisi lingkungan eksternal (the external environment), motivasi kelembagaan (institutional mativation), kapasitas kelembagaan (institutional capacity) dan kinerja kelembagaan (institutional performance). Kelem- bagaan yang terbentuk juga ditinjau dari tiga ciri utama kelembagaan yaitu batas yurisdiksi, hak dan kewajiban, aturan representasi sehingga efektifitas dan kebelanjutan kelembagaan dapat terjamin.

Berdasarkan hasil analisis, disarankan bahwa (1) Pengembangan agribisnis padi organik diperlukan kelembagaan yang terpadu dari kelembagaan dalam semua sub system agribisnis, (2) Pemerintah memiliki peran besar dalam pengembangan agribisnis padi organik sehingga kebijakan-kebijakan yang mendukung terlaksananya program agribisnis padi organik penting untuk ditingkatkan dan diperhatikan implementasinya, (3) Kelembagaan penunjang seperti Bapeluh, Lembaga keuangan, dan lembaga sertifikasi sangat diperlukan sehingga apabila akan mengembangkan padi organik peran lembaga-lembaga tersebut harus diperhatikan.

\section{DAFTAR PUSTAKA}

Adekunle. AA, J Ellis-Jones, I Ajibefun, RA Nyikal, S Bangali, O Fatunbi and A Ange. 2012. Agricultural innovation in sub-Saharan Africa: Experiences from Multiple-stakeholder Approaches. Ghana: Forum for Agricultural Research in Africa (FARA), Accra.

Colborn. T. 2006. A Case for Revisiting the Safety of Pesticides: A Closer Look at Neurodevelopment. Environment Health Perspect. Vol 114 No 1 Hlm 10-17

Cotula, Lorenzo, Moussa Djire and Ringo W. Tenga. 2008. The Right to Food and Access to Natural Resources: Using Human Rights Arguments and Mechanisms to Improve Resource Access for Rural Poor. Rome: Food and Agriculture Organization.

Arnold van Huis. 2012. An Innovation Systems Approach to Institutional Change: Smallholder Development in West Africa. Agricultural Systems Journal. 108 (2012) 74-83

Kusnandar dan Marimin. 2003. Pengembangan Produk Agroindustri Jamu dan Analisis Struktur Kelembagaannya. Jurnal Tekno- 
logi dan Industri Pangan Vol 14 No 1 Hlm 40-45.

Kusnandar, Totok Mardikanto, dan Agung Wibowo. 2009. Penanggulangan Kemiskinan Melalui Rekayasa Model Kelembagaan Pengembangan Agroindustri Pedesaan Skala Kecil di Kabupaten Karanganyar. Laporan Penelitian Hibah Strategi Nasional. Surakarta: LPPM UNS

Lieberherr, Eva. 2009. Policy Relevance of New Institutional Economics: Assessing Efficiency, Legitimacy and Effectiveness. Discussion paper series on the Coherence between institutions and technologies in Infrastructures. Netherlands: Ecole Polytechnique Fédérale de Lausanne, Switzerlan and Delft University of Technology

Litbang Deptan. 2007. Kelembagaan Agribisnis Industrial Pedesaan (AIP). http://www. primatani.litbang.deptan.go.id/index.php ?option=com_content\&task. Diakses tanggal 20 Pebruari 2011.

Nainggolan, K. 2005 Peningkatan Ketahanan Pangan Masyarakat dalam Rangka Revitalisasi Pertanian, Perikanan dan Kehutanan. Majalah Pangan Vol XIV No $45 \mathrm{Hlm}$ 3-14.

Pranadji, Tri. 2003. Reformasi Kelembagaan dan Kemandirian Perekonomian Pedesaan. Kajian pada Kasus Agribsinis Padi Sawah. Seminar Nasional Peluang Indonesia Mencukupi Sendiri Kebutuhan Beras Nasionalnya. Bogor: Badan Litbang Pertanian Departemen Pertanian.

Prasad, C. Shambu. 2007. Rethinking Innovation and Development: Insights from the
System of Rice Intensification (SRI) in India. The Innovation Journal: The Public Sector Innovation Journal, Volume 12 No 2 Tahun 2007

Purwaningsih, Yunastiti, Slamet Hartono, Masyhuri, Jangkung Handoyo Mulyo. 2010. Pola Pengeluaran Pangan Rumah Tangga Menurut Tingkat Ketahanan Pangan di Provinsi Jawa Tengah, Jurnal Ekonomi Pembangunan, Vol 11, No 2 Desember 2010 Hlm 236-253. Surakarta: Universitas Muhamadiyah Surakarta.

Saleh, R. Gozali dan Zaini. 2007. Analisis Kelembagaan Sistem Integrasi Padi Ternak. http://www.Bp2tp.litbang.deptan.go.id/ file/wp04_01analisiskelembagaan.

Diakses tanggal 12 Mei 2011.

Soekartawi. 2002. Prinsip Ekonomi Pertanian: Teori dan Aplikasi. Jakarta: Raja Grafindo Persada.

Sucihatiningsih, DWP. dan Waridin. 2010. Model Penguatan Kapasitas Kelembagaan Penyuluh Pertanian dalam Meningkatkan Kinerja Usahatani Melalui Transaction Cost: Studi Empiris di Provinsi Jawa Tengah., Jurnal Ekonomi Pembangunan, Vol 11, No 1 Juni 2010 Hlm 13-29. Surakarta: Universitas Muhammadiyah Surakarta.

Sutopo, HB. 2006. Metodologi Penelitian kualitatif Dasar teori dan Terapan dalam Penelitian. Surakarta: UNS Press.

Syahyuti. 2004. Model Kelembagaan Penunjang Pengembangan Pertanian di Lahan Lebak: Aspek Kelembagaan dan aplikasinya dalam Pembangunan Pertanian. Bogor: Puslitbang Sosial Ekonomi Pertanian. 